\title{
Implementation of Customer-based Brand Equity Strategy and Integrated Marketing Communication in Micro, Small and Medium Enterprises
}

\begin{abstract}
Tedi Setiawan ${ }^{1 *}$
${ }^{1}$ Universitas Pendidikan Indonesia

*Corresponding author.Email: tediate9@gmail.com

ABSTRACT

The majority of Micro, Small, and Medium Enterprises (MSMEs) do not have a brand to get customers as a means of marketing. A good product without the power of an effective brand and marketing strategy will end and be unsustainable. MSMEs will run stagnant and may experience setbacks if the Customer-Based Brand Equity Strategy and Integrated Marketing Communication are not implemented. Especially amid the conditions of the Covid-19 Pandemic and digital transformation, which requires adaptive and agile MSME players to face fast-paced changes. The research will be studied with a qualitative descriptive method approach through in-depth interviews with each source as many as 20 MSME actors who are developing in Bandung. The development of MSMEs requires a combination of the role of branding strategies in the organization as an internal factor and brand recognition through marketing communication as an external factor. The process of building a strong brand and marketing communication can transform the business of MSME players into large, successful brands.
\end{abstract}

Keywords: Customer Based Brand Equity, Integrated Marketing Communication, Micro Small Medium Enterprises.

\section{INTRODUCTION}

Micro, Small, and Medium Enterprises have a very significant role in the Indonesian economy, both in terms of the number of business units, employment, and contribution to Gross Domestic Product. In 2011, the number of MSMEs reached 55.2 million units. With this amount, MSMEs absorb 101 million workers and generate IDR 4,303 trillion or $57.9 \%$ of Indonesia's total Gross Domestic Income of IDR 7,427 trillion [1].

Currently, most of the Micro, Small, and Medium Enterprises Units do not have a brand to get customers such as business cards, brochures, catalogs, product designs, and eye-app-peal packaging as a means of marketing. Some of the Micro, Small, and Medium Enterprises Units question the benefits of branding if even with the current conditions their businesses can meet their daily needs. The attitude of the Micro, Small, and Medium Enterprises actors can be caused by several things, including because they do not understand the science of branding, do not have a positive entrepreneurial character, and have never received assistance[2]

A good product without the power of a brand and an effective marketing strategy will be useless and will not stay in the minds of consumers. If consumers are compatible with a product, they will not easily turn to other brands [3]. Brand strategy is a communication system that regulates all contact points with a product or service with stakeholders and directly supports the overall business strategy [4-5]. According to [6], what is included in the brand strategy includes brand positioning, brand identity, and brand personality. According to [7], which is also included in the brand strategy, namely brand communication.

Brand and brand management have become a wellknown management strategy and priority that has been the target of companies for many years [8]-[9]. Studies on brand strategies for micro, small and medium enterprises are still very minimal. Most studies on brands in large-scale businesses seem to ignore the fact that 95 percent of businesses in the world are micro, small, and medium enterprises [10]. The UMKM unit has become a 
starting point for becoming a large and global company [11].

In addition to the brand, consumers value a product or service based on the brand equity it has. Lassar et al. 1995 in [12] state brand equity as the consumer's perception of the superiority of the product that the brand has when compared to other brands. The stronger the brand equity that is owned, the more satisfied consumers will be in meeting their needs. On the other hand, the weaker the brand equity that is owned by a product or service, the less satisfied consumers are in meeting their needs so that this will encourage consumers to choose or switch to other products or services [13].

Consumer-based brand equity assessment (CustomerBased Brand Equity) is a different effect of consumer response to brand marketing [14] In the MSME Unit, both in the types of production, retail, and service businesses, brand equity is very important to be used as a strength in identifying and differentiating their products and services from other MSME players in the minds of consumers (Baily and Ball, 2006; Kim and Kim, 2005; Kayaman and Arasli, 2007; Prasad and Dev, 2000) [15][18].

A brand also has the benefit of providing legal protection for all features and aspects of the product, providing intellectual assets or ownership rights, as well as legal protection to brand owners and consumers, brands can greatly influence the decision to buy [19]. In limited financial conditions, MSME players need to find creative solutions, for example by utilizing Word of Mouth Marketing, Social Media, and mentoring activities optimally so that MSME players can make good product branding [20].

Operational risk is one of the risks that must be managed by MSME actors that occur due to negligence of human errors, internal process errors, system failures, and/or external events that affect business activities resulting in operational losses. [21]. Micro, Small \& Medium Enterprises will run stagnant and may experience setbacks if the Customer-Based Brand Equity Strategy and Integrated Marketing Communication are not implemented. Especially amid the conditions of the Covid-19 Pandemic and digital transformation, which requires adaptive and agile MSME players to face fastpaced changes.

\section{METHODS}

The type of research used by researchers is descriptive qualitative. According to [22], qualitative research methods are research methods used to examine the conditions of natural objects where the researcher is the key instrument.

Descriptive research is a research method that describes and interprets objects accordingly and as they are. Descriptive research is also called non-experimental research because, in descriptive research, the researcher does not manipulate the variables and also does not control the research variables.

In this study, the stages were carried out, namely by conducting in-depth interviews with 20 MSME actors, then reducing data to classify which data were used in uncovering the stages of the branding strategy so that a strategy formulation was obtained. branding and appropriate marketing communication strategies.

\section{RESULTS AND DISCUSSION}

\subsection{Discussion}

\subsubsection{The Role of Brand Management in Micro, Small \& Medium Enterprises}

The study discipline of Micro, Small, and Medium Enterprises is broadly based on studies in the fields of management, marketing, and entrepreneurship. It is argued that the three things that Micro, Small, and Medium Enterprises are unique enterprises that differ in their strategic, management, and marketing aspects compared to large companies [23]. Several other studies encourage the integration of strategic and marketing management in the context of Micro, Small, and Medium Enterprises [24].

Research conducted by Cohen and Stretch in [25] reveals that most of the problems faced by Micro, Small and Medium Enterprises actors are marketing problems. This confirms the research conducted by [26] regarding the key factors of effective marketing confirming that a good sales orientation broadly determines its marketing character. As a result, promotions that are driven to build brands are becoming more difficult for Micro, Small and Medium Enterprises to implement due to some funding limitations. In line with the research conducted by [25], it is found that in Micro, Small and Medium Enterprises, brand management has not received or a little attention in carrying out its business activities.

Based on the results of interviews with MSME actors, it is found that brand management is not yet a top priority in business activities. Business owners who are at the forefront of Micro, Small, and MediumEnterprises's activities rarely carry out brand management on their products and do not realize that brand management is an important concept in the success of their business. The concept of brand management is not deeply embedded in the activities of Micro, Small, and Medium Enterprises so that no worker is willing to pay sufficient attention to brand management/development activities.

This reality is a challenge in itself for owners or managers of Micro, Small, and Medium Enterprises to make brand management a priority in their business activities so that the sustainability of their business is 
maintained. [25] found that the company name is often not the same as the product brand name. In many cases, entrepreneurs of Micro, Small, and Medium Enterprises only issue one or two brands. And even then done individually without co-branding and collaborating with other Micro, Small, and Medium Enterprises actors.

This condition resulted in reduced opportunities for brands from Micro, Small, and Medium Enterprises players that we studied to get the attention of consumers. The role of business owners, in this case, is very important both internally and externally to prioritize brand management in their business activities. Micro, Small, and Medium Enterprises can explore the possibility of a co-branding or promotional cooperation with well-known brands while still paying attention to their budget and its suitability.

\subsubsection{Penentuan Branding Strategy Pada Jenis Usaha Mikro, Kecil \& Menengah}

Based on the results of interviews with MSME business owners, another problem faced in developing a branding strategy for Micro, Small \& Medium Enterprises is adjusting the type of business being undertaken with the branding strategy taken. In this study, brand development in Micro, Small \& Medium Enterprises based on the type of business of the interviewed respondents can be seen in Table 1 .

Table 1. Strategy Branding Based on Types of Micro, Small and Medium Enterprises

\begin{tabular}{|c|c|c|c|}
\hline $\begin{array}{l}\text { Brand } \\
\text { Type }\end{array}$ & Package Type & $\begin{array}{c}\text { Component } \\
\text { Type }\end{array}$ & $\begin{array}{c}\text { Customer } \\
\text { Interface Type }\end{array}$ \\
\hline $\begin{array}{l}\text { Product } \\
\text { Category }\end{array}$ & $\begin{array}{l}\text { Consumers are } \\
\text { free to choose } \\
\text { through } \\
\text { comparisons } \\
\text { with other } \\
\text { products } \\
\text { Distribution } \\
\text { through } \\
\text { independent } \\
\text { companies. } \\
\text { Example: } \\
\text { food, cleaning. }\end{array}$ & $\begin{array}{l}\text { Capital goods } \\
\text { that } \\
\text { consumers do } \\
\text { not directly } \\
\text { buy are for } \\
\text { example } \\
\text { industrial } \\
\text { goods. }\end{array}$ & $\begin{array}{l}\text { Products that } \\
\text { require services } \\
\text { such as airlines, } \\
\text { hotels, and } \\
\text { restaurants. }\end{array}$ \\
\hline $\begin{array}{l}\text { Strategy } \\
\text { Topic }\end{array}$ & $\begin{array}{l}\text { Emphasize } \\
\text { emotional } \\
\text { values and } \\
\text { differentiation } \\
\text { in which the } \\
\text { role of } \\
\text { advertising is } \\
\text { dominant. }\end{array}$ & $\begin{array}{l}\text { Understand } \\
\text { the interests } \\
\text { of } \\
\text { Stakeholders. }\end{array}$ & $\begin{array}{l}\text { Implementation } \\
\text { of internal } \\
\text { marketing to } \\
\text { increase } \\
\text { customer } \\
\text { satisfaction } \\
\text { through } \\
\text { communication. }\end{array}$ \\
\hline $\begin{array}{l}\text { Main } \\
\text { Target }\end{array}$ & $\begin{array}{l}\text { End } \\
\text { Consumers. }\end{array}$ & $\begin{array}{l}\text { Purchasing } \\
\text { Agent. } \\
\text { Consumer. } \\
\text { Public. }\end{array}$ & $\begin{array}{l}\text { Purchasing } \\
\text { Agent \& Clerk. }\end{array}$ \\
\hline
\end{tabular}

In the Package Type business, Micro, Small \& Medium Enterprises sell products that run out quickly or including Fast Moving Consumer Good (FMCG) such as food, cleaning products, candy, cakes, and others. Consumer behavior in purchasing FMCG is to always compare product features with one another so that the role of the brand becomes important. Consumers will associate a name with a certain category, to enable the achievement of top-of-mind positions. How to make our brand easy to remember and recognize, communication strategy becomes important. This can take the form of advertising, sales promotion, publications, sales force, and direct marketing. Wong and [23] put forward several suggestions to support marketing activities in Micro, Small \& Medium Enterprises, namely :

1. Invest in brands for the long term.

2. Develop a unique brand.

3. Develop awareness to employees of the importance of the company brand.

4. Communicate the brand consistently and clearly through all its marketing activities.

In the Component Type business, Micro, Small \& Medium Enterprises players sell goods needed by the industry. In this case, the role of the brand is less important, compared to consumer goods. The price of capital goods is relatively more expensive than the price of consumer goods, so the buying process is usually long and involves many parties.

In this type of business, the Customer Interface Type produces products that must be accompanied by service/services, for example, a car salesman accompanied by after-sales service. In managing this business, internal marketing plays an important role, namely the company trains and motivates its employees to serve customers well.

\subsection{Results}

\subsubsection{Model Management \& Brand Development for Micro, Small \& Medium Enterprises Based on Customer-Based Brand Equity}

Based on the results of interviews with respondents, we propose a model developed by [25] for the role of brand management in Micro, Small \& Medium Enterprises, which can be seen in fig. 1 . 


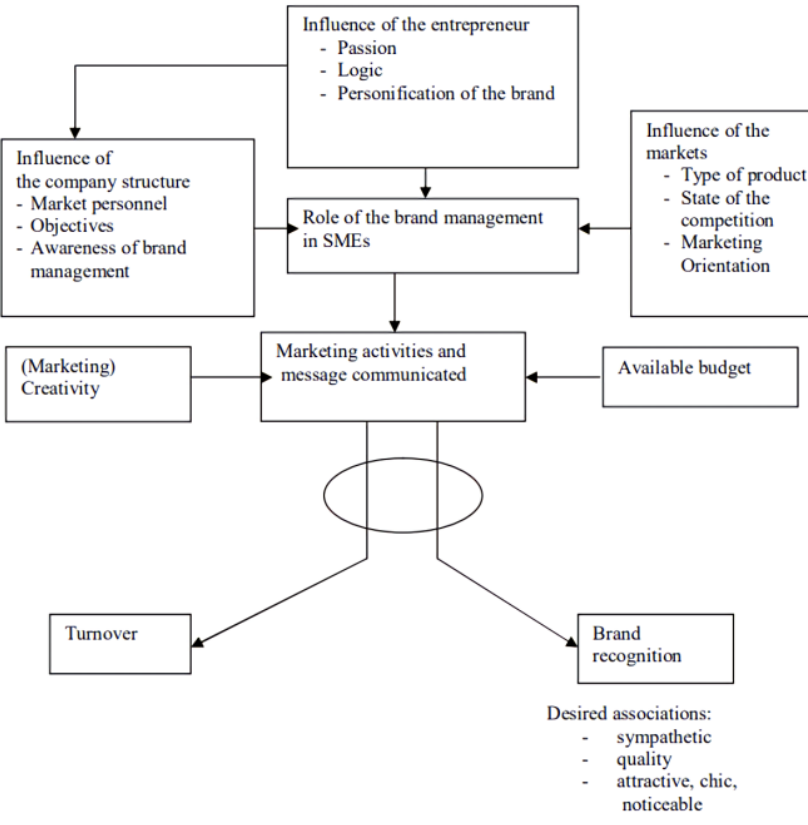

Figure 1 Brand management model in micro, small \& medium enterprises

In the model in fig. 1. it can be explained that Micro, Small \& Medium Enterprises actors play a dual role in this model. The first role, namely as a director and manager who must pay a lot of attention to brand management. The second role is as an entrepreneur, being the personification of the brand and playing an important role in communicating the brand in the business environment.

Furthermore, the proposed model for Micro, Small \& Medium Enterprise brand development combining the role of brand management in the organization (internal factors) with brand recognition (external factors) can be seen in fig. 2 below.

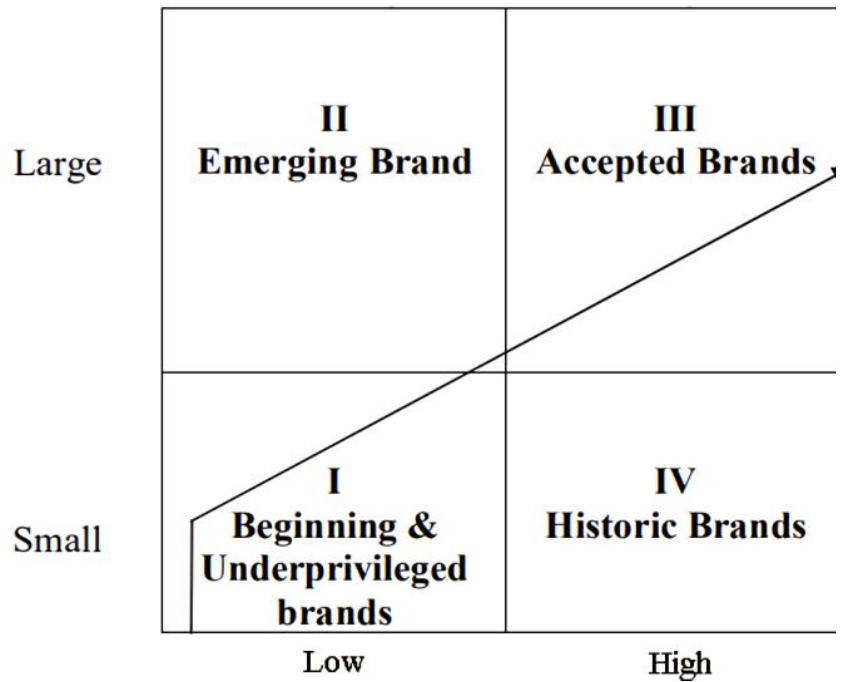

Figure 2 Brand development model in micro, small \& medium enterprises
In measuring brand recognition, there are no objective measurement criteria so a quadrant model for brand development is needed as a reference. The quadrant of the brand development model can be described as follows :

a. Quadrant I, Beginning and Underprivileged Brands. This stage is the initial stage of a brand. This quadrant is very important for creating added value for brands that have been created but have not been managed to create awareness among consumers. The role of brand management is needed to make a brand big and famous.

b. Quadrant II, Emerging Brand. Building a brand takes time. Brand recognition to consumers is not something that happens by itself and requires planned steps. In this quadrant, Micro, Small \& Medium Enterprises actors must make every employee in the organization aware of and support the importance of brand recognition and are willing to allocate company budgets for brand recognition.

c. Quadrant III, Accepted Brands. In this stage, the brands owned by Micro, Small \& Medium Enterprises have been accepted by some consumers. The company has achieved a high level of brand recognition. The company allows the benefits of success to be developed in the future.

d. Quadrant IV, Historic Brands. In this quadrant, some brands have been managed and are eligible to achieve a greater level of brand recognition.

\subsubsection{Brand Image Development as Media Integrated Marketing Communication}

In Micro, Small \& Medium Enterprises, increasing brand awareness of the products being marketed is not a top priority when a company determines its marketing budget. This causes the brand that is owned is not widely known by consumers. Micro, Small \& Medium Enterprises actors focus more on the sales aspect than the marketing aspect. Peterson in [27] found that product and sales orientation is more blinded than marketing orientation is related to brand management. Brands that are well known to consumers are one of the many important goals that every Micro, Small \& Medium Enterprise actor wants to achieve with the marketing budget they have.

The product brand is a representation of the owner, for that every Micro, Small \& Medium Business actor must try to introduce and communicate the brand they have to their consumers through the performance and good image inherent in the entrepreneur. Besides, entrepreneurs can use several communication media to introduce their products, through business cards, walls in front of buildings/houses/shops, and public transportation facilities. Another effective way for Micro, 
Small \& Medium Enterprises entrepreneurs to communicate their brand is through word of mouth, newspapers, and brochures. Word of mouth communication or word of mouth strategy is not only costly and costly but also very effective.

Reference [2] provides eight steps in communicating a strong brand for a company as an integrated marketing communication media, including:

a. Create a logo design that fits your business character and products. This logo can help brands that are created to appear more luxurious and special and shape customer communication

b. Determine the right target market. The target market is the main target of Micro, Small \& Medium Enterprises

c. Use Partnerships to Build Brand Awareness. Collaborating with influencer partners can increase brand awareness.

d. Be Consistent! Micro, Small \& Medium Enterprises must be consistent in using every logo and design equipment for their business so that they can increase brand awareness of their products.

e. Brand Positioning, which is a company activity to design offers and images to provide different values in the minds of consumers [28]

f. Brand Identity, according to [6], Brand identity is a set of aspects that convey what a brand stands for its background, its principles, its purpose, and ambitions.

g. Brand personality is a human trait found in a brand. Some say that brand personality is the way a brand communicates and behaves.

Brand Communication, which is the evaluation of a consumer's overall brand whether it is good or bad. Brand communication consists of packing, ad-advertising, surround (event), and direct marketing [29]. Brand communication summarizes the whole meaning of the effects of consumer behavior on their purchases [30]. Positive brand communication such as trust and brand loyalty is essential for long-term success and brand sustainability [31].

\section{CONCLUSIONS}

Based on the results and discussion above, the conclusions that can be drawn from this research include:

a. The role of a brand for a product is very important so that consumers can differentiate one product from another. To build a brand owned by Micro, Small \& Medium Enterprises so that it grows big and creates a strong relationship with the target market, good brand management is needed. b. Brand management is one of the answers to the problems faced by Micro, Small \& Medium Enterprises actors in the marketing aspect. Brand management has not become a priority in business activities so that the role of the owner is very important both internally and externally to prioritize brand management in business activities. For the application of brand management to be effective and as expected, Micro, Small \& Medium Enterprises actors must consider the types and strategies of their business.

c. In developing brands for Micro, Small \& Medium Enterprises, it is necessary to combine the roles of brand management in the organization as an internal factor and brand recognition as an external factor. In developing a brand, there are four stages which include Be-ginning and Underprivileged Brand, Emerging Brand, Accepted Brand, and Historic Brand.

d. The process of building a strong brand can transform a business from a small player to a successful big brand. As consumer trust in the brand increases, sales will also increase.

\section{ACKNOWLEDGMENTS}

I would like to express my gratitude to the University of Education of Indonesia for facilitation of my research results into the publication of scientific papers at the Global Conference on Business, Management, and Entrepreneurship. My thanks also go to the Conference Chair, Technical Chairperson, Scientific Committee team, and all GCBME members.

\section{REFERENCES}

[1] H. A. Sarwono, "Profil bisnis usaha mikro, kecil dan menengah (umkm),” Bank Indones. dan LPPI, 2015.

[2] S. D. Setiawati, M. Retnasari, and Diny Fitriawati, "Strategi membangun branding bagi pelaku usaha mikro kecil menengah," J. ABDIMAS BSI J. Pengabdi. Kpd. Masy. Vol., vol. 2, no. 1, 2019.

[3] Y. Pages, "Building customer loyalty," Solutions, pp. 2-5, 2001.

[4] H. S. Fatimah, R. MohdTajuddin, and Z. A. Shakir, "Creating resilient sme through brand identity (case study of bumiputera fashion entrepreneurs in malaysia)," Int. Acad. Res. J. Soc. Sci., vol. 1, no. 2, 2015.

[5] L. V. Rampl and P. Kenning, "Employer brand trust and affect: linking brand personality to employer brand attractiveness," Eur. J. Mark., vol. 48, no. 1, 2014, doi: 10.1108/EJM-02-2012-0113. 
[6] S. van Gelder, "The new imperatives for global branding: strategy, creativity and leadership," J. Brand Manag., vol. 12, no. 5, 2005, doi: 10.1057/palgrave.bm.2540234.

[7] D. Schultz and B. Barens, Strategic brand communication campaigns. 1999.

[8] J. Kapferer, The new strategic brand management: creating and sustaining brand equity long term kogan page series new strategic brand management: creating and sustaining brand equity series. 2008.

[9] K. L. Kotler, Philip dan Keller, Manajemen pemasaran, jilid 1. Jakarta: Erlangga, 2008.

[10] J. Storey, "An introductory guide to cultural theory and popular culture," J. Aesthet. Art Crit., vol. 52, no. 4, 1994, doi: 10.2307/432052.

[11] Rahab, "Penerapan manajemen merek pada usaha kecil dan menengah (ukm)," J. Bisnis dan Ekon., vol. 16, no. 1, 2009.

[12] R. B. Gil, E. F. Andrés, and E. M. Salinas, "Family as a source of consumer-based brand equity," J. Prod. Brand Manag., vol. 16, no. 3, 2007, doi: 10.1108/10610420710751564.

[13] W. Wisnu and A. Hermawan, "Pengaruh perceived quality terhadap kesetiaan merek dan citra merek," J. Manaj. dan Pemasar. Jasa, vol. 4, no. 1, 2011, doi: 10.25105/jmpj.v4i1.485.

[14] K. Keller, "Strategic brand management: building, measuring and managing brand equity," 2. Aufl., Up. Saddle River Prentice-Hall, 2003.

[15] R. Bailey and S. Ball, "An exploration of the meanings of hotel brand equity," Serv. Ind. J., vol. 26, no. 1, 2006, doi: 10.1080/02642060500358761.

[16] H. B. Kim and W. G. Kim, "The relationship between brand equity and firms' performance in luxury hotels and chain restaurants," Tour. Manag., vol. 26, no. 4, 2005, doi: 10.1016/j.tourman.2004.03.010.

[17] R. Kayaman and H. Arasli, "Customer based brand equity: Evidence from the hotel industry," Manag. Serv. Qual., vol. 17, no. 1, 2007, doi: 10.1108/09604520710720692.

[18] K. Prasad and C. S. Dev, "Managing hotel brand equity: A customer-centric framework for assessing performance," Cornell Hotel and Restaurant Administration Quarterly, vol. 41, no. 3. 2000, doi: 10.1016/S0010-8804(00)80014-2.

[19] G. Horan, M. O’Dwyer, and S. Tiernan, "Exploring management perspectives of branding in service SMEs," J. Serv. Mark., vol. 25, no. 2, 2011, doi: 10.1108/08876041111119831.
[20] A. T. Stephen, "The role of digital and social media marketing in consumer behavior," Current Opinion in Psychology, vol. 10. 2016, doi: 10.1016/j.copsyc.2015.10.016.

[21] A. Setiawan and E. Yulianto, "Implementation of risk control self assessments using rapid application development model in bank operational risk management process," J. Theor. Appl. Inf. Technol., vol. 97, no. 11, 2019, doi: 10.5281/zenodo.3256439.

[22] Sugiyono, "Metode penelitian," Penelitian, 2017.

[23] H. Y. Wong and B. Merrilees, "A brand orientation typology for SMEs: a case research approach," J. Prod. Brand Manag., vol. 14, no. 3, 2005, doi: 10.1108/10610420510601021.

[24] D. J. Carson, "The evolution of marketing in small firms," Eur. J. Mark., vol. 19, no. 5, 1985, doi: 10.1108/EUM0000000004739.

[25] F. G. B. J. M. Krake, "Successful brand management in SMEs: anew theory and practical hints," J. Prod. Brand Manag., vol. 14, no. 4, 2005, doi: 10.1108/10610420510609230.

[26] J. Hill, "A multidimensional study of the key determinants of effective sme marketing activity: Part 1,” Int. J. Entrep. Behav. Res., vol. 7, no. 5, pp. 171-204, 2001, doi: 10.1108/EUM0000000006006.

[27] R. C. Becherer, D. Halstead, and P. Haynes, "Marketing orientation in smes: effects of the internal environment," New Engl. J. Entrep., vol. 6, no. 1, 2003, doi: 10.1108/neje-06-01-2003-b003.

[28] R. Mitchell, K. Hutchinson, and B. Quinn, "Brand management in small and medium-sized (sme) retailers: a future research agenda," J. Mark. Manag., vol. 29, no. 11-12, 2013, doi: 10.1080/0267257X.2013.798672.

[29] C. Grönroos, "Keynote paper from marketing mix to relationship marketing - towards a paradigm shift in marketing," Manag. Decis., vol. 35, no. 4, 1997, doi: 10.1108/00251749710169729.

[30] A. Salehi and T. Roshandel Arbatani, "Is branding always beneficial? a meta-analysis of the relationship between branding and performance in SMEs," Adv. Environ. Biol., vol. 7, no. 14, 2013.

[31] P. Rufaidah, “Testing branding strategy development model,” Acad. Strateg. Manag. J., vol. 15, no. Specialissue3, 2016. 